Área Abierta. Revista de comunicación

audiovisual y publicitaria

ISSN: 1578-8393 / ISSNe: 1578-8393

EDICIONES

http://dx.doi.org/10.5209/ARAB.56602

\title{
La fotografía documental como recurso en la obra de mujeres artistas: de la flâneuse a la cronista de realidades inventadas
}

\author{
M. Dolores Clemente-Fernández; ${ }^{1}$ Nieves Febrer-Fernández²; M. del Mar Martínez- \\ Oña ${ }^{3}$.
}

Recibido: 04 de septiembre de 2016 / Aceptado: 02 de diciembre de 2017

Resumen. En este artículo revisamos la obra de una serie de mujeres creadoras que, durante el siglo XX, han investigado sobre la realidad de su entorno público y privado utilizando la fotografía documental como recurso artístico. El camino recorrido por estas artistas parte de su firme compromiso con la dimensión histórica (certificando que la idea del documento forma parte de la impronta fotográfica, debido a su naturaleza ontológica) y con la dimensión subjetiva (aquella que tiene que ver con la opinión de la artista). En los trabajos estudiados, la fusión del arte con el documental constituye una poderosa asociación mediante la cual la mujer se apodera de su entorno y de su misma imagen construyendo su propia visión de la realidad y de la identidad genérica.

Palabras clave: Documentalismo fotográfico; artistas fotógrafas; crónica urbana; construcción de la realidad; subjetividad; género

\section{[en] Documentary Photography as a Resource in the Work of Women Artists: From the Flâneuse to the Chronicler of Invented Realities}

\begin{abstract}
In this article we review the work of a series of creative women who have investigated during the twentieth century the reality of their public and private environment by the use of documentary photography as an artistic resource. The path walked by these artists is based on their firm commitment to the historical dimension (certifying that the idea of document is part of the photographic imprint, due to its ontological nature) and the subjective dimension (the one that deals with the opinion of the artist). In the studied works, the fusion of art and documentary provides a powerful association whereby women takes over its environment and of its own image constructing its own vision of reality and generic identity.
\end{abstract}

Keywords: Photographic Documentary; Female Photographic Artists; Urban Chronicle; Construction of Reality; Subjectivity; Gender

1 Universidad Internacional de La Rioja - UNIR (España)

E-mail: mariadolores.clemente@unir.net

2 Universidad Internacional de La Rioja - UNIR (España)

E-mail: nieves.febrer@unir.net

3 Universidad Internacional de La Rioja - UNIR (España)

E-mail:mar.martinez@unir.net 
Sumario. 1. Introducción: la fotografía documental como recurso artístico. 2. La artista, cronista de la vida urbana. 3. El documentalismo subjetivo. 4. Microhistorias fragmentadas y autobiografías ficcionadas. 5. Conclusiones. 6. Bibliografía

Cómo citar: Clemente-Fernández, M.D., Febrer-Fernández, N. y Martínez-Oña, M.M. (2018). La fotografía documental como recurso en la obra de mujeres artistas: de la flâneuse a la cronista de realidades inventadas. Área Abierta. Revista de comunicación audiovisual y publicitaria, 18 (1), 75-96. http://dx.doi.org/10.5209/ARAB.56602

\section{Introducción}

La fotografía, una de las pocas manifestaciones artísticas no excluyentes para la mujer, supuso un ámbito de experimentación y creación en el que las mujeres pudieron convertirse en productoras culturales de la sociedad de masas (Vadillo, 2010), explorando las posibilidades ofrecidas por la técnica fotográfica e indagando en sus propios recursos y mecanismos discursivos. Desde el comienzo, las artistas asumieron una posición dual: como protagonistas de una novedosa disciplina a la vez que creadoras de la misma al posicionarse a ambos lados de la lente como objeto y como sujeto (Muñoz y González, 2014), convirtiéndose en autoras de su imagen mediante la autorrepresentación. No obstante buena parte de sus trabajos, como el de las creadoras de otros ámbitos, han sido opacados, por lo que se hace preciso recuperar desde la perspectiva de género a la artista fotógrafa como protagonista que presenta una historia (su propia historia) de lucha por la libertad, favoreciendo con ello su visibilidad artística y la igualdad de género.

En este texto nos vamos a centrar en la fotografía documental como recurso empleado por las mujeres artistas para apropiarse del entorno y pergeñar una crónica filtrada por su subjetividad. Para ello partimos de dos supuestos: en primer lugar, hablamos de una utilización artística, de manera que la imagen resultante excede la categoría de documento; en segundo lugar, negamos la neutralidad y objetividad absolutas de la fotografía, tenga intenciones expresivas o no.

"La historia de la fotografía puede ser contemplada como un diálogo entre la voluntad de acercarnos a lo real y las dificultades para hacerlo" (Fontcuberta, 2002: 12), ya que precisamente es el carácter testimonial de la fotografía el que facilita su función como artefacto cultural transmisor de ideología (Solomon-Godeau, 2001). La aparente objetividad de la fotografía, magnificada cuando esta es concebida como documento, a veces nos hace olvidar que (como cualquier representación) siempre implica un proceso de elaboración consciente (e inconsciente) de la realidad y no su mero registro.

En esa selección/recreación/construcción de la realidad la fotografía documental implica además un posicionamiento político, de forma que el valor histórico y antropológico de las imágenes se combina con la reflexión y la crítica social. Dicho de otra forma, la documentalista ha encontrado tradicionalmente su razón de ser en la fidelidad "a un propósito enaltecido: descubrir una verdad oculta, preservar un pasado en extinción" (Sontag, 2006: 86). El carácter testimonial de la fotografía que congela un momento determinado - como diría Barthes (1989), el "esto ha sido" de la fotografía, conjugación "de realidad y de pasado" (121) que constituye "literalmente una emanación del referente" (126) - ha facilitado la presunción 
de realidad y de verdad de la imagen documental, teóricamente ajena a la ficción, especialmente cuando se mueve en el ámbito del fotoperiodismo. Ello ha permitido descuidar el hecho de que la elaboración de un mensaje (artístico, informativo o didáctico, categorías por otra parte no excluyentes) conlleva siempre una serie de elecciones que implican "construir una nueva realidad, al punto de que podemos hablar de una realidad inventada [...] desde donde se crean metáforas y grandes relatos sobre la sociedad y el mundo" (Aparici, 2010: 15). Pero, además de las decisiones tomadas por la creadora - la primera y más evidente, qué fotografiar y qué no-- el trabajo de parcelación de la realidad es un proceso bidireccional; el propio mundo representado también se reconstruye al saberse espiado por la cámara, estereotipándose y plegándose a criterios normativos internalizados e imbuidos de referencias estéticas, como ya apuntó en 1965 Bourdieu (2003) al referirse a la fotografía como práctica social: "lo 'natural' es un ideal cultural que hay que crear antes de poderlo fijar" (143).

Mediante el uso de la fotografía documental, la artista se posiciona como relatora de su tiempo, plasmando su personal percepción de su entorno cotidiano y evidenciando, en última instancia, su interés por tomar el control de dicho entorno y de su propia imagen como creadora - rompiendo con la tradición patriarcal de la historia del arte, que ha relegado a la mujer a la categoría de objeto representado- . Partimos de la hipótesis de que es precisamente la pretensión de autenticidad de la imagen concebida como documento, como registro histórico, la que la convierte en un medio idóneo para que las artistas expongan sus verdades y sus realidades particulares (incluso ficticias), recurriendo a estrategias más o menos manipuladoras. En este trabajo ofrecemos un recorrido de naturaleza fragmentaria y sin un continuum preciso, estudiando propuestas artísticas relevantes en el contexto occidental a lo largo del siglo XX atravesadas, asimismo, por un enfoque de género. De este modo, hacemos uso de una metodología de carácter historiográfico en la estela de lo que apunta el filósofo Walter Benjamin (1989a) en sus Tesis sobre la Historia - reflexiones escritas entre 1939 y 1940, en un contexto de guerra y huida de los nazis - , tratando de cepillar la historia a contrapelo. Un recorrido que, simulando el vagar de la flâneuse, nos lleva a varios momentos históricos clave: el papel de la mujer en la fotografía de fin de siglo, la irrupción de la fotografía directa, el documentalismo subjetivo ante los nuevos cambios sociales del último tercio del siglo XX y el potencial contradiscursivo de las prácticas fotográficas centradas en las microhistorias fragmentadas y autobiografías ficcionadas, obras performativas insufladas de teatralidad en las que la ficción resulta indistinguible de la realidad. Este extenso marco espacio-temporal obliga necesariamente a la síntesis, por lo que seleccionaremos las obras de artistas consolidadas cuyas trayectorias en Occidente sean significativas para cada uno de los altos en el camino de este recorrido discursivo articulado al modo de la crónica de una observadora flâneuse. Nuestro principal objetivo es, por tanto, plantear una propuesta de cartografía de artistas fotógrafas que nos permita transitar por sus diversos enfoques frente al concepto de fotografía como documento para establecer en qué medida ha influido en ello su condición identitaria de género. 


\section{La artista, cronista de la vida urbana}

La fotografía permitió, desde sus orígenes, que nuestras realidades se percibieran a través de episodios, fragmentos, situaciones, acontecimientos, objetos o personas. Y es que todo artista "es un investigador nato de la condición humana y de su tiempo" (Sanmartín, 2005: 18), así como de su imagen contemporánea, de sus espacios (multi-contextuales) y de sus diferentes trayectorias, historias y narraciones, algo que ya fue tenido en cuenta por las pioneras de la fotografía, tanto si se trataba de artistas, de fotógrafas profesionales o de aficionadas. Como ejemplos de esto último podemos citar las extensas colecciones de Eulalia Abaitua (1853-1943) y de Vivian Maier (1926-2009), que dejaron constancia de sus realidades más cercanas.

La concepción del artista como un cronista de su tiempo - una suerte de antropólogo de lo cotidiano, que destapa los entresijos de la vida social y de la esfera íntima, la emoción oculta tras los gestos banales, la grandeza y la miseria agazapadas detrás de cualquier esquina - remite a Baudelaire, que en su obra El pintor de la vida moderna (1863) concibe la ciudad como un gran escaparate o vitrina que ofrece sus escenas al observador perspicaz. Poniendo el acento en la visualidad, Baudelaire (1995) describe al artista como un cronista, más concretamente como un paseante (un flâneur) que vaga sin rumbo por las calles de la ciudad, un bohemio con los ojos ávidos de espectáculo que se sumerge en las multitudes pero sin confundirse con ellas: "ver el mundo, estar en el centro del mundo y permanecer oculto al mundo" (87). Si bien Baudelaire nunca tuvo en alta estima a la fotografía, la figura del flâneur resultó muy provechosa para la teorización del medio; así, Sontag (2006) considera al fotógrafo como:

\footnotetext{
Una versión armada del paseante solitario que explora, acecha, cruza el infierno urbano, el caminante voyeurista que descubre en la ciudad un paisaje de extremos voluptuosos [...]. Al flâneur no le atraen las realidades oficiales de la ciudad sino sus rincones oscuros y miserables, sus pobladores relegados, una realidad no oficial tras la fachada de vida burguesa que el fotógrafo "aprehende" como un detective aprehende a un criminal (85).
}

La artista fotógrafa reivindica su condición de flâneuse $e^{4}$ haciendo efectiva mediante la fotografía la conquista del espacio público, reclamación histórica de los movimientos sufragistas y en pro de la liberación de las mujeres: haciendo uso de ella la artista se compromete con su entorno y se sitúa en una posición privilegiada para interpretar los acontecimientos siempre cambiantes del presente. Esta situación rompe con lo tradicionalmente establecido por la sociedad patriarcal, posibilitando a la mujer ejercer una profesión fuera del ámbito del hogar (Campelo, 2012). No obstante cabe puntualizar que los lugares "permitidos" variaban según la clase social, ya que la correspondencia entre género masculino/esfera pública y género femenino/

4 El flâneur baudelairiano es una figura esencialmente masculina. La mujer artista de la segunda mitad del XIX poseía un campo de acción mucho más limitado, lo que redundaba en una predominancia de los espacios privados y en una visión muy reducida de los públicos, acotada a aquellos social y moralmente aceptados para las mujeres. Mientras el flâneur recorría libremente las calles con actitud despreocupada, la mujer que paseaba sola se arriesgaba a manchar su reputación y/o a ser confundida con una prostituta — descrita por Baudelaire como "un objeto de placer público" (1995: 130)—. Sobre ello, remitimos a los trabajos de Pollock (2008) y Transforini (2009). 
esfera privada era propia de la burguesía pero no del proletariado, donde la condición de mujer trabajadora implicaba por tanto problematizar la misma definición de "lo femenino" y establecer distinciones culturales entre mujeres (Pollock, 2008).

A la hora de documentar su entorno (tras el cambio de siglo), algunas artistas se adscribieron a planteamientos acordes con la fotografía directa. Este movimiento, surgido a comienzos del $\mathrm{XX}$, tenía como objetivo la búsqueda de una nueva estética a través de las propias características de su medio de expresión, es decir, liberando a la fotografía de las influencias de la pintura, de la escenificación e incluso de los montajes; en suma, se trataba de revindicar la fotografía como un arte propio y moderno, cuyo principal atractivo es la captación de la imagen directa. Sin embargo hasta el período de entreguerras no se disolverán las antinomias poesía/verdad y estilo/ documento, señaladas por Didi-Huberman (2014) como propias de una discusión inane que pretende tornar en excluyente el carácter dual de la fotografía (esto es, como expresión estética y como testimonio). Ello sucederá gracias al llamado "estilo documental", que justamente observaba el valor artístico de las obras como fruto de las cualidades técnicas y de "la especificidad documental de su medio de expresión" (Lugon, 2010: 21).

Exponente de ese estilo fue la artista estadounidense (inicialmente escultora) Berenice Abbott (1898-1991), que se formó como fotógrafa en París vinculada al ambiente vanguardista, más concretamente el surrealista, ejerciendo como ayudante de su compatriota Man Ray (1890-1976). Al igual que este, Abbott se interesó por la obra fotográfica del francés Eugène Atget (1857-1927), adquiriendo tras su muerte sus series urbanas parisinas. En estos "documentos" - denominados así por el propio Atget (Guasch, 2011: 28) - se registran tanto los lugares como el paso del tiempo, lo que queda remarcado en aquellas imágenes tomadas por Atget en un mismo sitio y tomadas repetidas veces varios años después. Las fotografías de Atget, con un claro exceso de detalles y texturas (las molduras, los descansillos y las escaleras, las puertas, las ventanas, las chimeneas, la corteza y las ramas de los árboles, los reflejos del agua, los reflejos de los cristales de los comercios, etc.), forman parte de extensos catálogos documentales que representan ecosistemas urbanos (aunque despojados de sus habitantes) por los que los surrealistas se sintieron irremediablemente atraídos (en especial, por sus reproducciones de los escaparates parisinos). Estas imágenes de un París vacío de humanidad impactaron a Benjamin (1989b), que las calificó como "pruebas en el proceso histórico" (31) equivalentes a las fotografias tomadas en la escena de un crimen que permiten recoger indicios, paisajes fragmentados que generan extrañamiento al descubrir una ciudad "desamueblada como un piso que no hubiese todavía encontrado inquilino" (1989c: 76). Atget también realizó un trabajo sociológico titánico documentando el París marginal en su serie Les Zoniers (1912-1913), que retrata la vida cotidiana de los habitantes empobrecidos que vivían miserablemente en la periferia de la ciudad.

Abbott desempeñó un esfuerzo formidable para que toda la obra de Atget no se perdiera, por lo que "el mundo del arte está en deuda con ella. En los catálogos y libros sobre Berenice Abbott, todos los autores contemplan y reconocen el esfuerzo que realizó para colocar a Atget en el lugar que le correspondía en la historia de la fotografia" (Núñez y Oliva, 2011: 135). Pero mientras que a los surrealistas les interesaba de Atget "su extraña sensación de vacío y la capacidad de duplicar el mundo como un signo, a Abbott le atraía lo que percibió como su esencia realista 
pura" (Weissman, 2011: 14) si bien el realismo de sus trabajos "puede ser [...] definido no como lo que 'realmente' hay sino como lo que 'realmente' se percibe" (Sontag, 2006: 172). En relación a su propia obra, en 1929 Abbott se trasladó de París (en donde había permanecido desde 1921) a Nueva York, trocando su interés inicial en el retrato por la crónica fotográfica de la ciudad. En sus imágenes, Abbott se aparta de Man Ray y muestra una metodología similar a la de Atget, narrando el flujo efímero de la actividad de la gran ciudad, la arquitectura, la población diversa alojada en ella y el reemplazo constante de lo antiguo por lo nuevo (imágenes 1 y 2), plasmando cómo "en la experiencia estadounidense [...] incluso el pasado inmediato se desgasta, despeja, demuele, desecha y canjea constantemente" (Sontag, 2006: 121). El resultado de este proyecto fue su obra más destacada, la publicación Changing New York (1939), en donde registra un país marcado por la Gran Depresión en el que conviven la riqueza y la pobreza, pero sin centrarse en la visibilización del dolor humano provocado por la crisis - como hará, por ejemplo, Dorothea Lange (18951965), buscando el protagonismo de las víctimas en sus emocionales imágenes para la Farm Security Administration (imagen 3) - . En su lugar, "analiza las consecuencias sociales y culturales del avance capitalista centrándose en el cambio de la fisonomía urbana" (Campelo, 2012: 250).

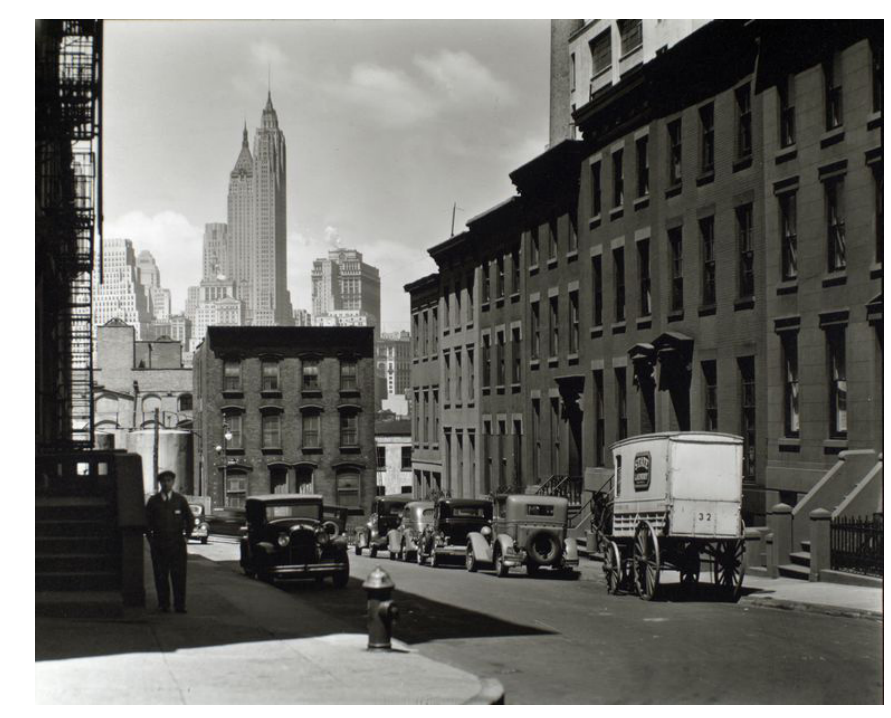

Imagen 1: Berenice Abbott, 1936: Willow and Poplar Street, Looking East [sic, view is actually looking toward Manhattan], Brooklyn [Fuente: The Miriam and Ira D. Wallach Division of Art, Prints and Photographs, The New York Public Library]

$5 \quad$ En el original: "its weird sense of emptiness and ability to redouble the world as a sign, Abbott was drawn to what she perceived as its pure realist essence". 

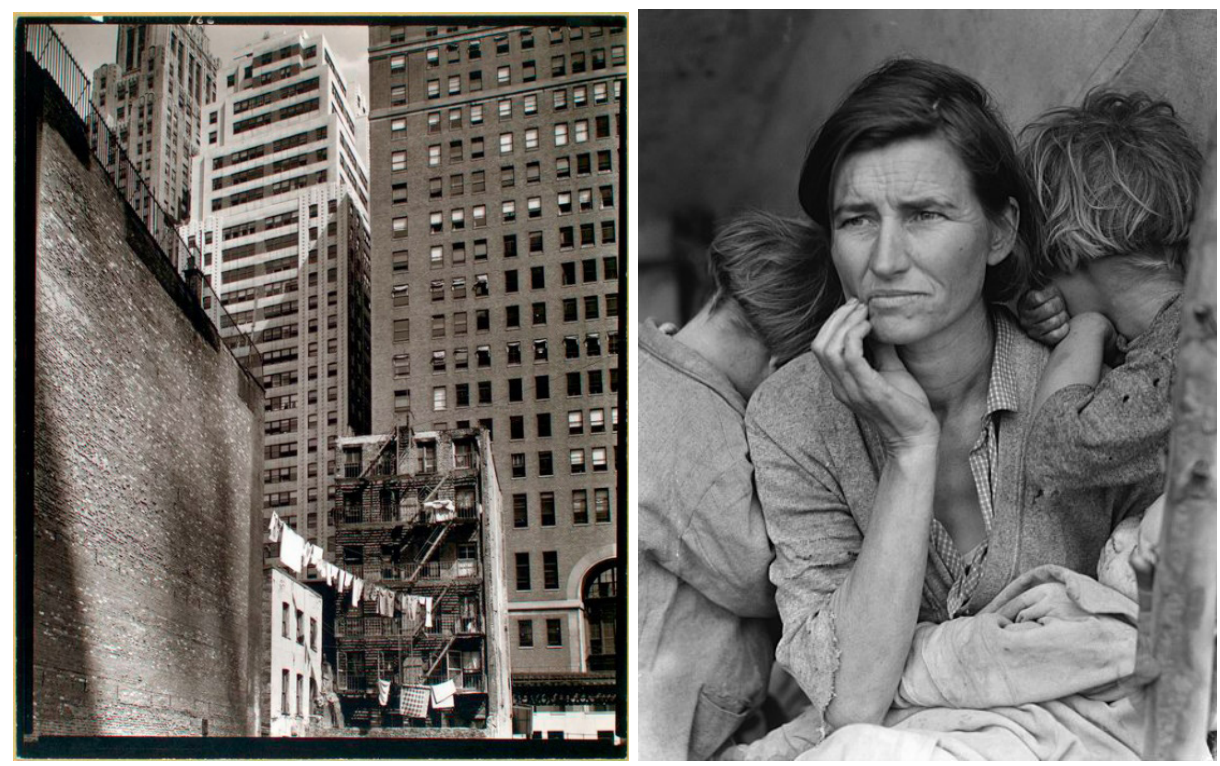

Imagen 2 (izquierda): Berenice Abbott, 1936: Construction Old and New, from Washington Street \#37, Manhattan [Fuente: The Miriam and Ira D. Wallach Division of Art, Prints and Photographs, The New York Public Library]. Imagen 3 (derecha): Dorothea Lange, 1936: Migrant Mother [Fuente: Library of Congress Prints and Photographs Division, Washington, D.C.].

A través de la crónica de la metrópoli (París, Nueva York, Berlín, Londres, etc.), del ecosistema urbano, se construye una nueva percepción del individuo que facilita la comprensión de nuestra sociedad contemporánea, así como sus implicaciones políticas, sociales y económicas. En esa captación del microcosmos urbano, la documentalista — retomando el rol de la flâneuse - se posiciona a menudo en los márgenes de lo social, yendo a la caza de motivos no convencionales que ponen en tela de juicio los discursos ideológicos dominantes y que se niegan a dejar fuera de marco sus contradicciones y aristas.

En los trabajos de la austriaca Lisette Model (1901-1983) o de la estadounidense Diane Arbus (1923-1971) — que fue alumna de la primera en la New School for Social Research de Nueva York - subyace una mirada antropológica que observa la ciudad como el lugar en el que los otros viven o sobreviven, se exhiben o se camuflan, se distancian o se aproximan en interacciones "efímeras basadas en la apariencia, la percepción inmediata y relaciones altamente codificadas y en gran medida fundadas en el simulacro y el disimulo" (Delgado, 1999: 12). La vida urbana, por tanto, se asemeja a "un gran baile de disfraces" en el que "el espacio público es el ámbito por antonomasia del juego, es decir de la alteridad generalizada" (Delgado, 1999: 14). De la primera destacamos su serie Promenade des Anglais (hacia 1934), dedicada a la alta sociedad de Niza, y sus imágenes de la década de 1940 sobre la vida nocturna neoyorquina, realizadas en locales como el Café Metropole (imagen 4), el cabaret del Bowery Sammy's o el Hubert's Flea Circus de Times Square. De la segunda, sus retratos de los considerados marginados, inadaptados o freaks, de todos 
aquellos habitualmente invisibilizados, considerados no fotografiables por salirse de lo normativo (imagen 5).
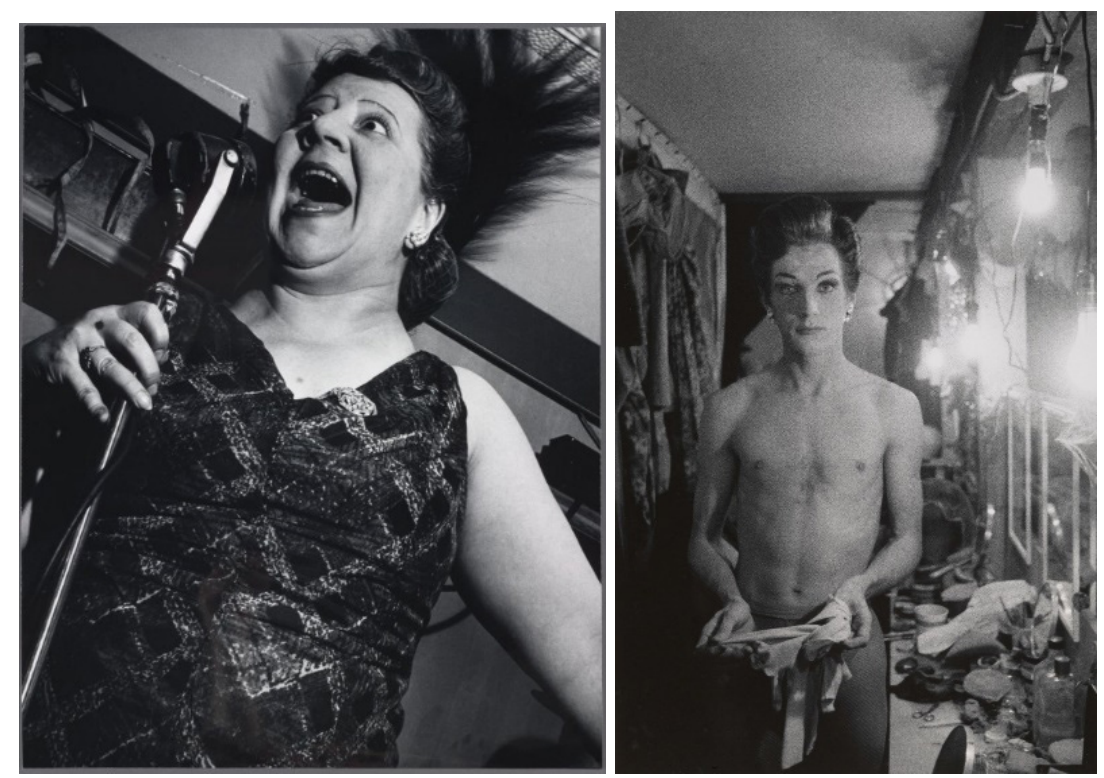

Imagen 4 (izquierda): Lisette Model, 1940: Singer at the Café Metropole, New York City

[Fuente: The Miriam and Ira D. Wallach Division of Art, Prints and Photographs, The New York Public Library]. Imagen 5 (derecha): Diane Arbus, 1959: Female Impersonator Holding Long Gloves, Hempstead, L.I. [Fuente: The Estate of Diane Arbus, LLC].

Tanto Model como Arbus evidencian el interés por los modos de representar las diferentes etiquetas identitarias, no solamente de género, sino también de clase y de grupo étnico, algo que se ha relacionado con su condición de mujeres judías (Moore y Moore, 2006). En lo relativo a la praxis artística, la obra de ambas testimonia la importancia de pasear por la ciudad (Lapeña, 2014): la salida del hogar equivale al inicio de una aventura en la que puede producirse un encuentro inesperado, una escena insólita, una experiencia inolvidable, una revelación imprevista o el hallazgo de un objeto prodigioso (Delgado, 1999). Como declaró su amigo y colega Marvin Israel, para Arbus lo más importante no era la obra artística en sí misma sino la experiencia que la originaba: la fotografía equivalía a un trofeo o recompensa obtenida tras una aventura (Lubow, 2003).

\section{El documentalismo subjetivo}

En la década de 1970 la fotografía documental artística se escindió en dos posicionamientos teóricos: uno que abogaba por la impersonalidad de la fotografía 
y el rol neutral del fotógrafo ${ }^{6}$ y otro (el que veremos aquí) que reivindicaba la experiencia y subjetividad personal como el único modo de acercarse a la realidad. En el segundo, denominado "documentalismo subjetivo", se "reivindicaba el yo sin renunciar a la estética documental" de forma que el mundo captado por la cámara actuaba como "pantalla sobre la que esos fotógrafos proyectaban sus propias vivencias, sus maneras de ver y de sentir" (Fontcuberta, 2002: 98).

La subjetividad de la artista fotógrafa toma plena conciencia en esta etapa en asuntos sociales, mediante el compromiso con el feminismo en sus múltiples facetas (abordajes teóricos marxistas, postestructuralistas, psicoanalíticos, etc.) - que, en el ámbito de las artes, tomó como preocupación inicial el cuestionamiento de la estructura patriarcal que afirmaba la hegemonía de la subjetividad del hombre, blanco y heterosexual, convirtiéndola en canónica e impulsando prácticas que silenciaban a las mujeres creadoras y coartaban su talento, caso del ensayo pionero de 1971 de Linda Nochlin (1989) que plasmaba una dinámica de poder en la que lo masculino era percibido como "neutro" y lo femenino como "intruso o disidente"-, con los movimientos estudiantiles y antibélicos que se venían gestando en la calle y en las universidades desde la década de 1960 o a través de la identificación personal e intelectual con espacios, grupos sociales, etnias o subculturas determinadas (Fontcuberta, 2002; Hebdige, 2004).

Así por ejemplo, Margaret Harrison ${ }^{7}$ (n. 1940), Mary Kelly (n. 1941) y Kay Hunt (1933-2001) adoptan en su proyecto artístico Women and Work: A Document on the Division of Labour in Industry 1973-75 una estética documental para articular un discurso feminista en diálogo con el marxismo (Mayayo, 2011) que denuncia la explotación sufrida por la mujer entrecruzando las categorías de género y clase social. Women and Work pone de relieve las diferencias laborales y salariales entre géneros en una fábrica de Bermondsey (Londres), aportando testimonios y datos - en diversos soportes: papel, fotografías en blanco y negro y películas) - que transmiten las experiencias vitales de las trabajadoras visibilizando la marginación que sufren. Pero en su proyecto también se deduce la desigualdad vivida en el interior del hogar, donde todo el peso recaía en la mujer. Así, las artistas pidieron a los empleados y las empleadas que resumieran un día corriente de trabajo. Mientras que los primeros se centraban en sus actividades en la fábrica, las segundas le daban mucha más importancia a la vida doméstica, ya que para ellas el trabajo se extendía antes y después de la jornada laboral. Es en este aspecto, apenas explorado por las artistas, donde radica la parte más endeble de la obra:

Harrison, Hunt y Kelly se habían centrado en estudiar las diferencias laborales entre hombres y mujeres en el ámbito del trabajo mercantil sin darse cuenta de que éste era inseparable de la esfera del trabajo doméstico. Al circunscribir su investigación al entorno de la fábrica, asumían sin pretenderlo esa dicotomía privado-público en la que se basa la división del trabajo en el capitalismo. Si los varones ocupaban los puestos más cualificados en la industria era, en gran medida, porque había todo un campo diferente de trabajo, invisible y no remunerado, que alguien — sus mujeres, sus madreshacía en su lugar, porque existía [...] una relación estrecha, en términos económicos, entre la esfera "pública" de la fábrica y la esfera supuestamente "privada" del hogar (Mayayo, 2011: 20).

6 Tal es el caso de la generación de fotógrafos alemanes de la "Escuela de Düsseldorf" (Candida Höfer, Axel Hütte, Andreas Gursky, Petra Wunderlich, etc.), que abogaban por una fotografía objetiva y distanciada. Para más información sobre este tema, que excede nuestras intenciones, remitimos al texto de Grigoriadou (2012).

7 En 1970, Harrison fue una de las fundadoras del London Women's Liberation Art Group. 
El compromiso social tiñe igualmente la obra conceptual de la neoyorquina Martha Rosler (n. 1943), que investiga sobre temas relacionados con la comunicación, los medios masivos, el urbanismo y cómo estos afectan al ser humano. En The Bowery in Two Inadequate Descriptive Systems (1974-75) plantea veinticuatro paneles en los que empareja fotografías de tiendas y fachadas del Bowery, un barrio deprimido de Nueva York, con textos mecanografiados ${ }^{8}$ que recogen expresiones populares dedicadas a la borrachera, remarcando la incapacidad de ambos lenguajes para transmitir la vida cotidiana del barrio y sus problemas subyacentes (Redondo, 2011). En contraste con la tradición fotográfica documentalista, que se centraría en los aspectos más míseros y pintorescos del Bowery, Rosler destierra a la figura humana de sus composiciones negándose a estetizar su sufrimiento y forzando al espectador a reflexionar y a rellenar los huecos faltantes, imaginando a los habitantes de esos escenarios vacíos y sus problemas. En esa línea, Sontag (2006) ofreció en su libro Sobre la fotografía (publicado inicialmente en 1973) una imagen desencantada de los documentalistas, observándolos como miembros de las clases acomodadas que testimoniaban realidades sociales desde la distancia, como si se tratase de curiosidades. Retomando la tradición de Atget frente al sentimentalismo de muchas imágenes de la Farm Security Administration, Rosler critica "la actitud irresponsable de quienes disparan sobre conflictos ajenos sin preocuparse antes por conocerlos, confiados en la objetividad de sus cámaras" (Redondo, 2011: 386).

La confrontación entre la disciplina fotográfica y los conceptos de objetividad y verdad constituye el eje de la obra de la estadounidense Nancy Burson (n. 1948). Pionera en la utilización de tecnología informática, Burson parte del simulacro para reflexionar acerca de la construcción cultural de la identidad, la raza y el género, centrándose en el rostro humano. Su obra Mankind (An Oriental, a Caucasian, and a Black Weighted According to Current Population Statistics) (1983-85) compone un rostro ficticio que amalgama características raciales diferentes, sintetizando visualmente el concepto de humanidad. Con ello subvierte la obsesión decimonónica por identificar de forma certera los tipos raciales mediante la fotografía y por analizar la fisiognomía para extraer correspondencias entre las características físicas y las morales ${ }^{9}$. Eliminando de la ecuación al referente, Burson pone de relieve que "la 'realidad' de la fotografía y la 'inmutabilidad' de los tipos raciales [...] estaban determinados culturalmente y que cada uno servía para reforzar al otro" (Pultz, 2003: 26). En Warhead I (1982) plasma la amenaza nuclear inherente a la guerra fría en un retrato compuesto por la suma de los rostros de una serie de líderes políticos (de manera que el porcentaje empleado de cada uno de ellos correlacione con la proporción de las cabezas nucleares disponibles en sus respectivos países): Ronald Reagan (55\%), Leonid Brezhnev (45\%), Margaret Thatcher, François Mitterrand y Deng Xiaoping (los tres últimos, menos del 1\%).

Además de por las amplias resonancias sociales y culturales de la guerra fría, las dos últimas décadas del siglo XX estuvieron marcadas por la enfermedad del

8 No obstante, los tres primeros paneles no contienen ninguna imagen, para dotar de más peso al texto en el conjunto.

9 En el XIX la fotografía fue una herramienta común en la medicina, en la psiquiatría y en la criminología para recopilar los rasgos propios de enfermos y delincuentes. Francis Galton (1822-1911), padre de la eugenesia, la utilizó profusamente componiendo numerosos retratos-tipo mediante sobreimpresiones de rostros de individuos con características similares (por ejemplo, padecer la misma enfermedad o haber cometido delitos equivalentes). 
SIDA; como apunta Sontag (1996), "el SIDA no deja lugar a romantización ni sentimentalización algunas, quizá porque está demasiado fuertemente asociado con la muerte" (109). La enfermedad transformó a nivel mundial la manera de entender el sexo y sus consecuencias y en Estados Unidos convulsionó de tal modo que muchos de los valores existentes hasta el momento (como, por ejemplo, el movimiento hippie de las décadas de 1960 y 1970) fueron completamente cuestionados y hasta cierto punto omitidos (De Diego, 1992), produciéndose una vuelta hacia posiciones familiares más conservadoras. Esto último se vio reflejado en la obra de muchas artistas estadounidenses. En Until That Last Breath: Women With AIDS (198797), Ann P. Meredith (n. 1948) fotografía a mujeres afectadas por la enfermedad para combatir el estigma, plasmando que esta no entiende de fronteras, géneros, orientaciones sexuales o grupos sociales (imagen 6).

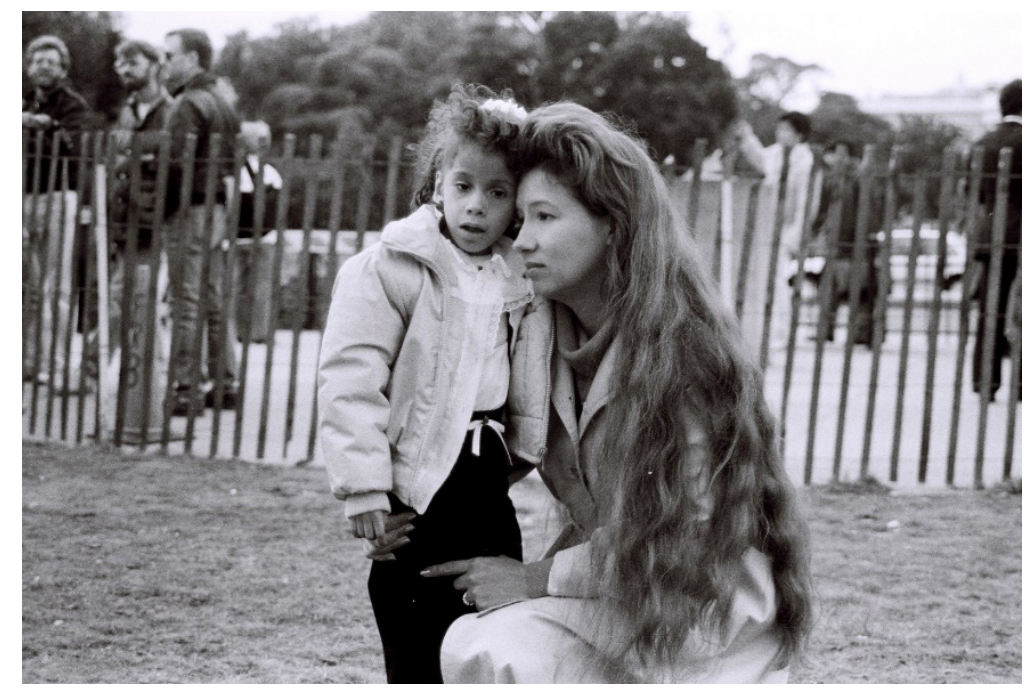

Imagen 6: Ann P. Meredith, 1988: Eleana and Rosa at the Ellipse at the White House

[Fuente: Colección Ann P. Meredith]

El documento fotográfico de esta época reivindica además una imagen multicultural de la realidad femenina. En la serie Domestic (1995-98), Catherine Opie (n. 1961) plasma la vida cotidiana de parejas de lesbianas para romper con los estereotipos fundamentados en el rechazo, mostrando que la intimidad de los hogares de las familias LGBTI es exactamente igual que la de cualquier otra familia heterosexual.

El documentalismo subjetivo no solamente adquiere la forma de militancia ideológica, también de aproximación emocional a la realidad fotografiada y vindicación de la experiencia cotidiana. Las vivencias propias y ajenas cristalizan en imágenes fragmentarias que condensan relatos de corte biográfico o autobiográfico. En sus series fotográficas, Nan Goldin (n. 1953) erige una crónica directa y sincera del panorama contracultural neoyorkino del que forma parte, efectuada desde el acercamiento personal y afectivo a los sujetos fotografiados (entre los que se incluye 
ella misma). Su cámara recoge sus experiencias y expone sus secretos más íntimos, lo que permite reflexionar acerca de los límites entre lo público y lo privado, lo que debe ser enseñado y lo que no, así como sacar a la luz las miserias y contradicciones de la vida burguesa, la pobreza, las drogas, la violencia, la soledad, las adicciones de diverso tipo y los mencionados estragos del SIDA. El trabajo de Goldin amplía por tanto el concepto de "álbum familiar, acogiendo no sólo bodas sino también funerales, no sólo velitas de cumpleaños sino también palizas y hematomas, no sólo amigos y amantes cuando nos hacen muecas divertidas o carantoñas cariñosas sino también cuando se drogan, mean o follan" (Fontcuberta, 2002: 59). En su obra más famosa, La balada de la dependencia sexual (1982-95), Goldin recoge fragmentos de microdramas que componen una narración de la vida sexual y amorosa en la que el placer y el dolor están íntimamente entrelazados (imagen 7).

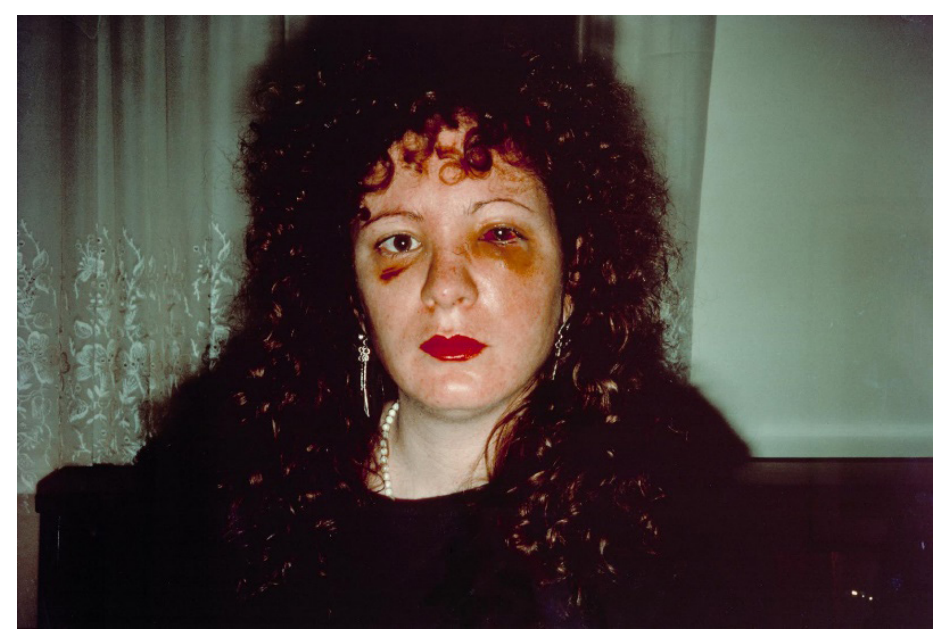

Imagen 7: Nan Goldin, 1984: Nan One Month After Being Battered [Fuente: Tate Museum] 


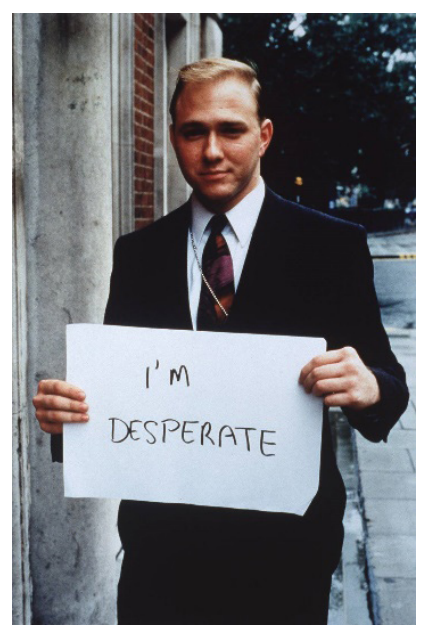

Imagen 8: Gillian Wearing, 1992-93: “I'm Desperate” (Signs...) [Fuente: Tate Museum \& Maureen Paley/ Interim Art, Londres]

Utilizando una estrategia diferente, la inglesa Gillian Wearing (n. 1963) desarrolla en sus obras procesos comunicativos en los que descubre información sobre la identidad ajena y que le permiten conocerse mejor a sí misma (Howgate, 2017); en palabras de Augé (2001), "la identidad sólo se construye poniendo a prueba la alteridad" (62). La obra fotográfica de Wearing realizada durante la década de 1990 subraya la necesidad de establecer una comunicación interpersonal con el retratado, reflexionando sobre la información proporcionada por la imagen, los relatos construidos a posteriori sobre ella y el rol del narrador.

En Signs that Say What You Want Them To Say and Not Signs that Say What Someone Else Wants You To Say (1992-93), la artista penetra en el espacio de los transeúntes y entabla diálogo con ellos, proponiéndoles que escriban en un papel lo primero que se les pase por la cabeza y se dejen retratar (imagen 8). Las imágenes resultantes de Signs... rompen la dinámica de la fotografía documental al posibilitar la intervención del sujeto retratado sobre su propia representación. En Theresa (1998), Wearing actúa como mediadora dejando que sean los otros los que se expresen. Es una serie fotográfica basada en la vida real de una mujer llamada Theresa, desempleada y alcohólica, a la que conocemos únicamente de forma parcial y subjetiva, a través de sus imágenes y las descripciones sobre ella manuscritas por sus siete parejas, lo que permite introducir narrativas relativas a temas como el género, la marginación y el alcoholismo. Toda esta serie es una fabricación, ya que representar al otro es siempre ficcionarlo.

\section{Microhistorias fragmentadas y autobiografías ficcionadas}

Como podemos apreciar, algunos de los trabajos anteriores implican lo que Fontcuberta (2002) denomina "la muerte del objeto" (22), de tal manera que ponen fin a la hegemonía histórica concedida a la realidad fotografiada en pro de 
la subjetividad del sujeto, centrándose en aspectos poéticos o metalingüísticos. La desconexión con el objeto fotografiable se verá facilitada por la tecnología digital, que dinamitará definitivamente la idea de la imagen como huella del referente.

En este apartado vamos a profundizar en aquellos enfoques que, siguiendo a Fontcuberta (2002), se liberan de la "seducción de lo real" (41), evidenciando que "crear equivale a manipular" (126) y que "toda fotografía es una ficción que se presenta como verdadera" (15). Ello implica decantarse por la planificación, la escenificación y el retoque, adoptando una metodología totalmente opuesta a la empleada en la fotografía directa. En este sentido, el artista y teórico Jeff Wall (n. 1946) explica estas dos modalidades de asumir la imagen mediante la metáfora del cazador y del agricultor: el primero acecha y captura a su presa mientras que el segundo la produce y cosecha (Fernández, 2007).

En torno a las décadas de 1960 y 1970 surgen en prácticamente todas las disciplinas artísticas, sociales y académicas, los denominados estudios de género y/o feministas, centrados en reestructurar acciones androcéntricas. En este contexto, la estética fotográfica y audiovisual se adecúa perfectamente a los discursos feministas. Además, tal y como exponíamos al inicio del artículo, las mujeres artistas fueron unas de las grandes beneficiarias del uso de la fotografía desde prácticamente sus orígenes, al tratarse de una técnica que no estaba históricamente acotada por los artistas masculinos: "la naturaleza del proceso fotográfico eliminaba la connotación de mano maestra y genial (masculina), se facilitó el acceso en igualdad de condiciones a una materia artística nueva que, aparentemente, tenía condicionantes automáticos" (Vadillo, 2010: 22). La construcción identitaria femenina ha sido un tema artístico recurrente en muchas artistas (por ejemplo, a través de acciones, performances y body art) que abrió la puerta a otros colectivos, principalmente minorías sociales y comunidades LGBTI (Álvarez, 2003).

A este respecto, es preciso mencionar el trabajo de dos artistas pioneras que desarrollaron narrativas en torno al proceso de construcción de la imagen femenina, reflexionando sobre la conformación de su propia identidad: la francesa Claude Cahun — pseudónimo de Lucy Renée Mathilde Schwob (1894-1954) — y la alemana Gertrud Arndt (1903-2000).

Cahun, fotógrafa y escritora prácticamente desconocida y olvidada durante buena parte del siglo XX, fue una de las primeras en hacer uso del autorretrato performativo, en el que manipula artificialmente su propia imagen como un modo de deconstruir su identidad llevándola a la indefinición, rechazando los estereotipos asociados a los géneros y haciendo de cada uno de sus retratos un ready made (imagen 9). Desde muy temprana edad y hasta su muerte, Cahun no dejó de investigar dentro del campo del disfraz y de los objetos y, claro está, de la fotografía como un objeto en sí mismo. El redescubrimiento de su obra durante la década de 1990 se produjo paralelamente a las formulaciones teóricas de Judith Butler (2007), que rechazaba el binarismo occidental y denunciaba la ideología implícita a la naturalización de los conceptos de sexo y género.

Arndt incorporó el disfraz como parte del imaginario de la mujer, explorando las posibilidades del autorretrato enmascarado y analizando los significados asociados a los objetos femeninos y el rol que estos desempeñan en las nuevas formas de narración identitaria (imagen 10). A pesar de su formación autodidacta, Arndt también introdujo aspectos técnicos relacionados con la vanguardia fotográfica, por ejemplo, superponiendo imágenes o realizando originales tomas y puntos de vista. 

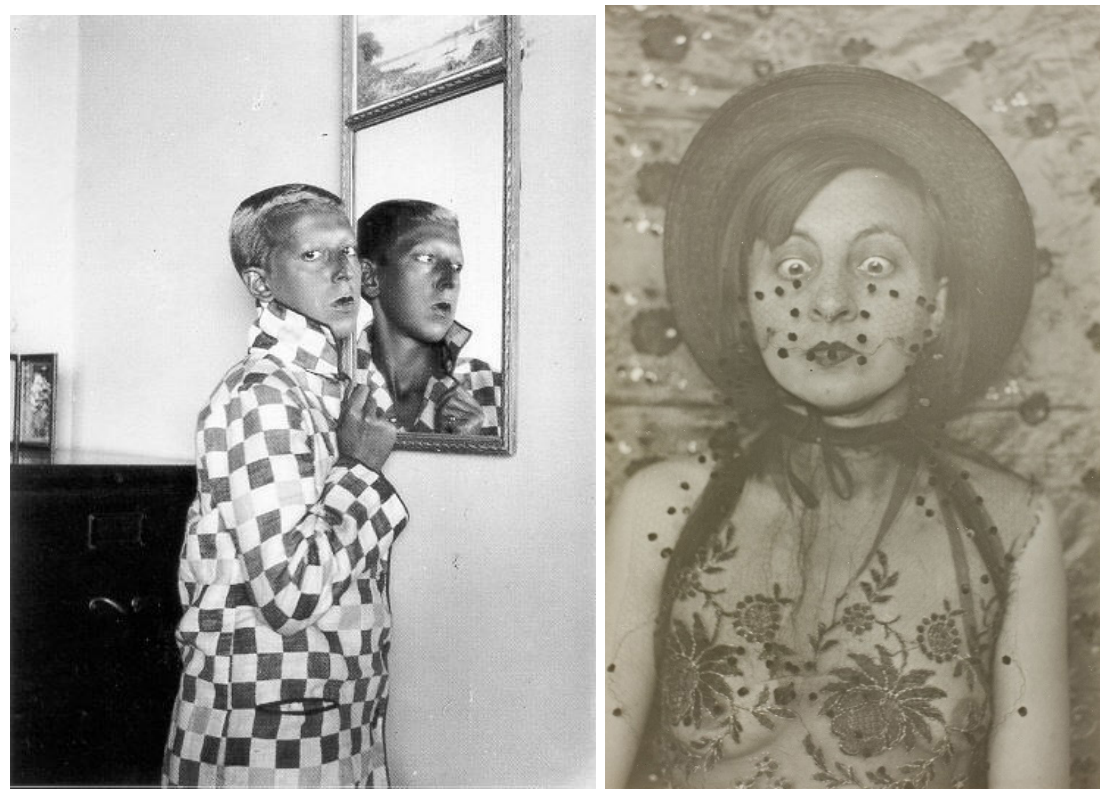

Imagen 9 (izquierda): Claude Cahun, 1928: Self-Portrait [Fuente: Jersey Heritage Collection]

Imagen 10 (derecha): Gertrud Arndt, 1930: Untitled (Masked Self-Portrait, Dessau) [Fuente: The Art Institute of Chicago/David Travis Fund].

Cahun y Arndt, con sus trajes y sus atuendos, abrieron un prometedor abanico relacionado con la metamorfosis y el fetichismo. Gran parte de sus trabajos nos recuerdan inevitablemente a la obra de otras fotógrafas como Carolee Schneemann (n. 1939), Gina Pane (1939-1990), Hannah Wilke (1940-1993), Valie Export (n. 1940), Adrian Piper (n. 1948), Ana Mendieta (1948-1985), Cindy Sherman (n. 1954), Tracey Moffatt (n. 1960), Janine Antoni (n. 1964) o Mariko Mori (n. 1967). Y no solamente por la fuerza estética de las fotografías y por su alto grado de contemporaneidad e ironía, sino por todo el entramado reflexivo que hay detrás: juegos de sexualidad, identidades polimorfas, arte corporal o la ambigüedad entre lo masculino y lo femenino. Todo ello nos conduce a investigar la identidad como una mascarada que conlleva una pluralidad de rostros y de imágenes que se complementan con toda una amplia gama de accesorios: ropa, maquillaje, joyería, etc. Algo que va unido, a su vez, a cuestiones de género, alteridad, otredad, roles, simulacros, escenificación, narcisismo, fetichismo y andrbgipriagnando sus relatos reconstruidos, subyace lo que LeVitte (2002) llama el melodrama: un estado mental, un adjetivo y una manera de ser que caracteriza el tiempo en que vivimos, en el que estamos empapados e inmersos en imágenes y microhistorias que exageran la verdad y producen falsificaciones que amplifican el sentido dramático de nuestras vidas. Las artistas fotógrafas juegan con la dimensión histórico-referencial de la fotografía para elaborar micronarraciones que revelan que todo ejercicio de corte biográfico y/o autobiográfico constituye un proceso de ensamblaje constante en el que se priman unos fragmentos frente a otros y se les dota de sentido (Chevrier y Pijollet, 2013). 
De todas las artistas mencionadas en el párrafo anterior, nos centraremos en tres: la estadounidense Sherman, la australiana Moffatt y la japonesa Mori. Todas ellas, al igual que la francesa Calle, se toman a sí mismas como estrellas de sus trayectorias artísticas. Algo que deriva en un proceso de construcción de "mitologías personales" a base de retales que dramatizan experiencias individuales, lo que refleja cómo las mismas, o su recuerdo, están constreñidas por las racionalizaciones culturales (Chevrier y Pijollet, 2013).

En la serie Untitled Film Stills (1977-80) de Sherman cada fotografía se asemeja a un fotograma de un filme (imágenes 11 y 12). La artista utiliza el disfraz como medio de adaptación para encarnar a diversos personajes femeninos minuciosamente caracterizados e insertados en ambientes de atmósfera cinematográfica que sugieren posibles narrativas inspiradas, principalmente, en el cine de las décadas de 1950 y 1960, en la televisión y en las imágenes de la prensa y revistas de moda. En esta obra no podemos hablar de autorretratos como tales ya que de la artista (persona) Cindy Sherman no sabemos nada: tenemos una serie de "yoes" ficcionados, una identidad absolutamente colectiva (pública) y una deconstrucción constante de la mujer (Baqué, 2003). Sherman ofrece un crisol de personajes y situaciones estereotipadas que evidencian "lo femenino" como una representación, como una categoría social modelada por las imágenes difundidas por los medios masivos.

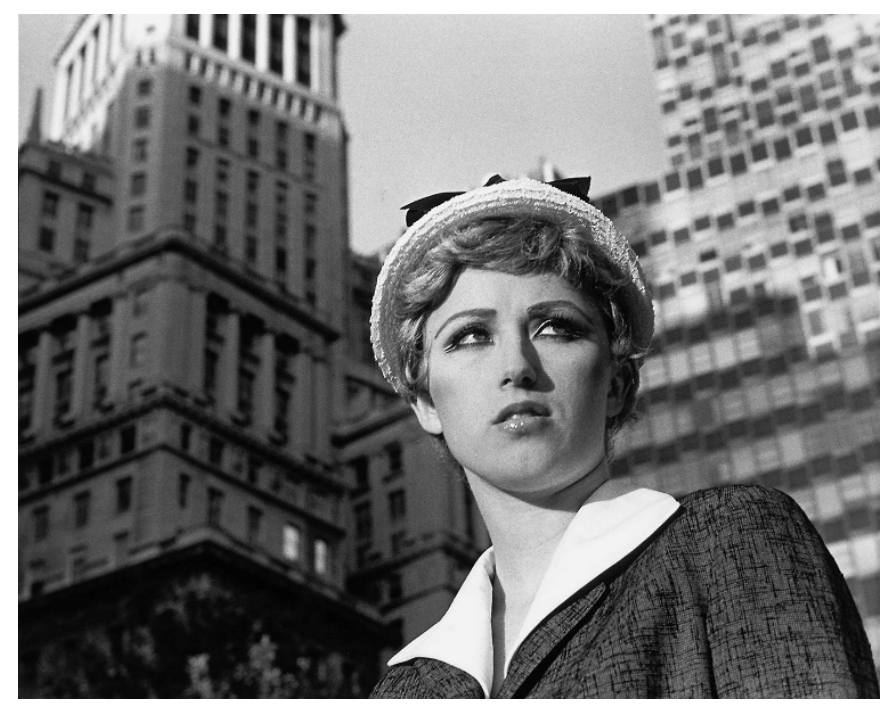

Imagen 11: Cindy Sherman, 1978: Untitled Film Still \#21 [Fuente: The Museum of Modern Art, New York] 


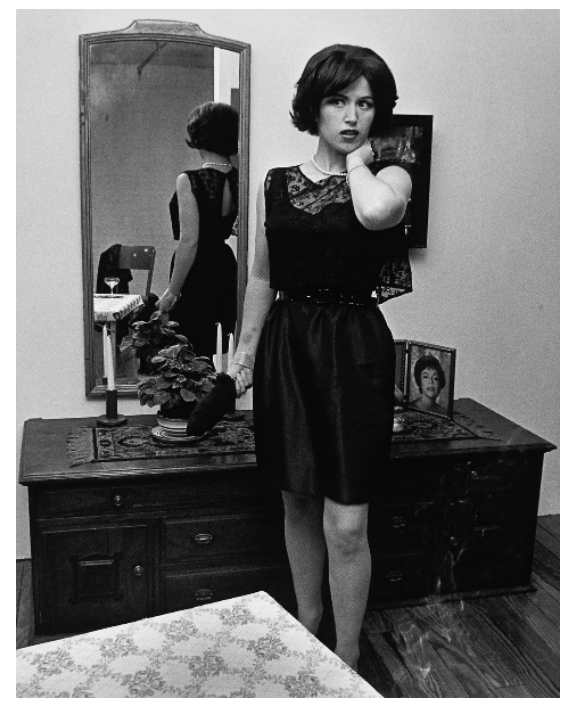

Imagen 12: Cindy Sherman, 1978: Untitled Film Still \#14 [Fuente: The Museum of Modern Art, New York]

El conflicto de relaciones e identidades rodea el trabajo de la fotógrafa y cineasta Moffatt, interesada en los estereotipos y las dinámicas de pertenencia-exclusión articuladas mediante categorías socioculturales como el género, la raza y la clase. En sus diferentes series fabrica historias en las que la memoria es un elemento crucial, insertando notas autobiográficas y retratándose ella misma interpretando diversos roles. En Scarred for life (1994) construye un álbum de nueve imágenes aisladas en las que la yuxtaposición de textos y fotografías evocan conflictos en la infancia y adolescencia. En Up in the Sky (1997) hace uso de la ficción para denunciar una práctica muy real llevada a cabo por las autoridades australianas, consistente en arrebatar a los niños y niñas aborígenes de sus familias para criarlos en orfanatos forzando la aculturación. De hecho, la propia artista fue criada por una madre adoptiva blanca, si bien no perdió el contacto con su madre biológica aborigen (Morris, 2006). Las veinticinco imágenes en blanco y negro de esta serie componen, en este sentido, una narración fragmentada y no lineal que potencia los sentimientos de pérdida, frustración y desarraigo (imagen 13). 


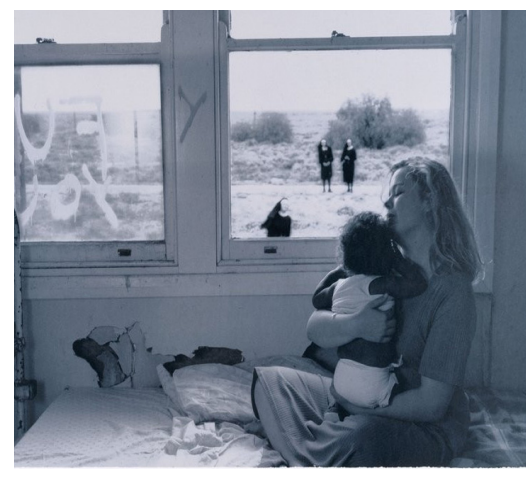

Imagen 13: Tracey Moffatt, 1997: Up in the Sky, 1/25. [Fuente: Museum of Contemporary Art Australia (MCA)]

La obra de Mori nos ofrece su particular visión de género, un imaginario postmoderno donde se desdibujan las fronteras entre lo natural y lo artificial, lo real y lo virtual, lo humano y lo tecnológico. Especialmente en su obra más temprana, aparece transformada en personajes futuristas e hipersexualizados inmersos en escenas de la vida cotidiana fácilmente reconocibles (imagen 14): la heroína espacial que viaja en un vagón de metro en Subway (1994), la geisha que sorprende a los transeúntes en el distrito financiero de Tokio con una taza de té en Ceremony of tea (1994), la prostituta chic hablando por el móvil en Red Light (1994) o la andreida de Play With Me (1994) que espera solícita en el escaparate de una tienda. En estos trabajos y en otros como Birth of a Star (1995), en donde encarna a una estrella pop vestida de colegiala — reinterpretada años después en Star Doll (1998), una muñeca al estilo de las figuritas de merchandising -, en sus posteriores personificaciones espirituales asiáticas — más relacionadas con la búsqueda de un alma colectiva que parece haberse extraviado en el Japón del mundo global一, o en sus vídeos de esculturas espaciales y tecnológicas, Mori da una visión múltiple y dividida de sí misma.

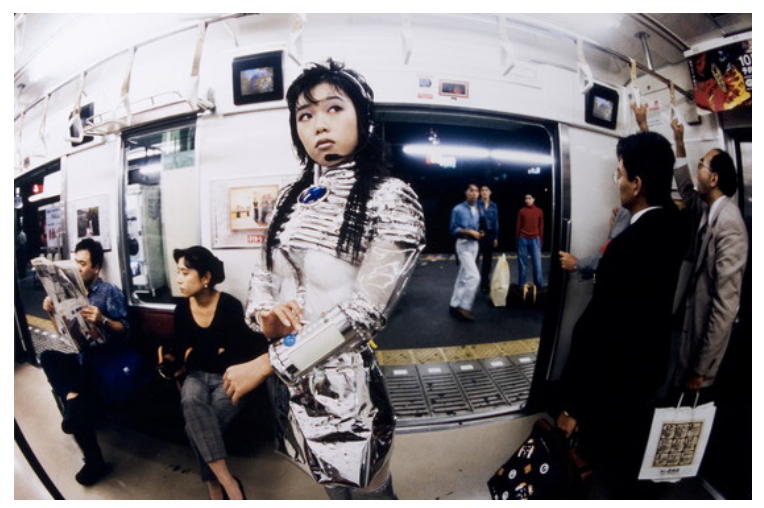

Imagen 14: Mariko Mori, 1994: Subway [Fuente: Los Angeles County

Museum of Art (LACMA)] 
Pero hablar de la conjunción realidad y ficción, del encuentro y la escenografía, del relato, episodios, microhistorias fragmentadas y de autobiografías, es hablar, sin lugar a dudas, de la fotógrafa y escritora francesa Sophie Calle (n. 1953), una autora que ha hecho de sí misma y de su trabajo una narración continua. En las obras The Sleepers (1979), Suite Vénitienne (1980), The Shadow (1981), Hotels (1981) o True Stories (1988-2003), por citar algunos ejemplos, se plasma cómo la vida de los individuos está formada por una serie de anécdotas, fragmentos y episodios que se superponen, relatan y reconstruyen. Calle toma sus propias vivencias, ficticias o reales, como el principal componente de su investigación artística, convertida en un proceso de documentación autobiográfica, pero también de construcción no exento de artificios teatrales. Su obra se sitúa por tanto en el ámbito de la experiencia, sin importar si es propia o ajena o si se ha documentado, recreado o creado (Colt, 1996).

Calle deja decidir al espectador la frontera que separa la realidad de la ficción. Para realizar The Shadow, datada el jueves, 16 de abril de 1981, le pidió a su madre que contratara a un detective para que siguiera sus pasos y tomase notas y fotografías. El origen de esta pieza es el deseo de Calle por saber cómo la describen, como la desean, para poder verse y describirse a sí misma. Es un trabajo que constituye un laberinto, una obra cerrada y edificada sobre sí misma como objeto y sujeto de la trama.

En True Stories (1988-2003) recoge sucesos cotidianos quizá no sucedidos a través de imágenes y textos. Dentro de esta serie, la subserie The Husband (1992) está dividida a su vez en varias piezas (El encuentro, El rehén, La disputa, La amnesia, La rival, La falsa boda, La ruptura, El divorcio y El otro) que relatan, por medio de fragmentos, la relación sentimental de Calle con el fotógrafo estadounidense Greg Shephard: cómo se conocen, el matrimonio, sus disputas y su separación. La recreación de esta relación se completa mediante el filme No Sex Last Night (1992), que recoge un viaje de la pareja desde Nueva York a California en un Cadillac gris combinando el cine documental con los códigos de la road-movie:

La artista cuenta cómo, respecto a la película y por cuanto se refiere a las posibles interrelaciones entre realidad y ficción, es decir, entre acción y argumento, todo lo que en ella aparece es verdad, es decir, ocurrió en realidad; pero al mismo tiempo, las operaciones de montaje de un film, con todo lo que conllevan de selección y de intención, acaban por convertirlo en un producto mucho más cercano a la ficción (Clot, 1996: 19).

En el filme, la cama es un componente fundamental dentro de la narración fílmica que indica el paso del tiempo. La imagen recurrente de la cama, acompañada de la voz en off de la artista diciendo "no sex last night", es el resultado directo de su relación con Greg. Casi todos los días el viaje de la pareja termina en el mismo punto: una cama vacía, deshecha y en la que no ha habido sexo como metáfora de la incomunicación entre ambos.

En los fotorrelatos o fotobiografías de Calle el texto y la imagen son dos elementos indisociables que se combinan para potenciar un pretendido efecto de veracidad: ambos son tratados formalmente como pruebas testimoniales de las experiencias que conforman sus proyectos. Así, las imágenes adquieren una apariencia casual mientras que los textos "oscilan entre un pretendido objetivismo fotográfico, cercano al informe, al inventario o al cuaderno de campo, y el subjetivismo propio del diario personal o de viaje" (Prieto, 2014: 50). 


\section{Conclusiones}

La recuperación de las diferentes expresiones artísticas de las mujeres creadoras desde la perspectiva de género manifiesta la importancia de la mirada de la mujer no solamente dentro de la historia de la fotografía, sino como un elemento fundamental, aunque opacado por la cultura androcéntrica, dentro de la crónica histórica y social de la contemporaneidad. Las imágenes fotográficas son objetos culturales que aportan datos significativos en la reconstrucción histórica de las sociedades y que, especialmente, señalan cómo estas fueron representadas. Desde su aparición, la fotografía ha posibilitado mostrar las distintas realidades socioculturales de la mujer, permitiendo a las artistas producir intervenciones (auto)biográficas, testimoniales y/o crónicas, explorando en sus imágenes la vida cotidiana de las mujeres protagonistas de sus propias historias, incardinadas en el centro de la narración-y reflexionando sobre los distintos posicionamientos del rol de autora-narradora.

La fotografía intenta reproducir con exactitud el referente, entendiendo que hay que convertir al sujeto en objeto plástico, transformarlo en colores y líneas, planos y manchas, utilizarlo y reconstruirlo. Pero, como podemos apreciar en el recorrido efectuado, las manifestaciones artísticas que emplean como recurso la fotografía documental se han distanciado progresivamente del referente. En última instancia, la reinvención de la realidad fotografiada enfatiza que nuestra misma visión del mundo está construida simbólicamente a través del lenguaje y de la cultura.

A lo largo del siglo pasado, la fotografía como expresión de género se ha escindido en tres grandes corrientes. En la primera, mediante la adopción de un documentalismo supuestamente objetivo con connotaciones antropológicas, la fotógrafa se iguala profesionalmente al fotógrafo adecuándose a los mismos principios y posicionándose como sujeto creador de pleno derecho. En la segunda, la fotografía empieza a cuestionar los límites de lo "real" - especialmente, a partir de la década de 1960, cuando la práctica fotográfica se reconduce hacia nuevos planteamientos sobre la naturaleza misma de su lenguaje - ; las artistas se distancian de la mirada masculina, preponderante en la historia del arte, elaborando trabajos que se apartan de la noción de objetividad introduciendo reflexiones sociales y discursos sobre la identidad como constructo de decisiones estéticas. En la tercera, en sintonía con los movimientos afines al postmodernismo, la artista no solo manipula la realidad sino que la construye trascendiendo el concepto de fotografía como documento y convirtiéndose en una creadora multidisciplinar; un proceso indisoluble de la búsqueda, estudio y análisis de la identidad como un fenómeno múltiple radicado en la cultura y no en la naturaleza.

A lo largo de estas tres corrientes la fotógrafa, entendida en su sentido más amplio, se erige como la artista fundamental en la configuración del mismo feminismo: la fotografía se revela como uno de los campos de mayor expansión para la interpelación feminista, desarrollando un nuevo cuestionamiento sobre su propio discurso. Las claves estéticas manejadas durante el siglo XX propician el paso de artistas que inmortalizan su visión de la realidad, negándose además a asumir un papel marginal, a constructoras de significados que reinventan y redefinen la fotografía como tal desde la perspectiva de género. 


\section{Bibliografía}

Álvarez Reyes, Juan Antonio. (2003). "No todo es documental". En Monocanal [cat. exposición]. Madrid: Museo Nacional Centro de Arte Reina Sofía, 31-37.

Aparici, Roberto. (2010). "La construcción de la realidad”. En Roberto Aparici (Coord.), La construcción de la realidad en los medios de comunicación. Madrid: UNED, 11-22.

Augé, Marc. (2001). Ficciones de fin de siglo. Barcelona: Gedisa.

Baqué, Dominique. (2003). La fotografía plástica. Un arte paradójico. Barcelona: Gustavo Gili.

Barthes, Roland. (1989). La cámara lúcida. Nota sobre la fotografía. Barcelona: Paidós.

Baudelaire, Charles. (1995). El pintor de la vida moderna. Murcia: Colegio Oficial de Aparejadores y Arquitectos Técnicos.

Benjamin, Walter. (1989a). "Tesis de filosofía de la historia”. En Walter Benjamin, Discursos interrumpidos I. Buenos Aires: Taurus, 175-192.

- (1989b). "La obra de arte en la época de su reproductibilidad técnica". En Walter Benjamin, Discursos interrumpidos I. Buenos Aires: Taurus, 15-58.

-. (1989c). "Pequeña historia de la fotografía". En Walter Benjamin, Discursos interrumpidos I. Buenos Aires: Taurus, 61-84.

Bourdieu, Pierre. (2003). Un arte medio: ensayo sobre los usos sociales de la fotografía. Barcelona: Gustavo Gili.

Butler, Judith. (2007). El género en disputa. El feminismo y la subversión de la identidad. Barcelona: Paidós.

Campelo Tenoira, Mariola. (2012). "Lucia Moholy y Berenice Abbott: fotografía de arquitectura". De Arte, núm. 11, 243-262.

Chevrier, Jean François y Pijollet, Élia. (2013). Formas biográficas. Construcción y mitología individual. Madrid: Siruela.

Clot, Manel. (1996). "Figuras de la identidad. Relatos privados, dispositivos ficcionales y autobiografías retóricas". En Sophie Calle. Relatos [cat. exposición]. Barcelona: Fundación La Caixa, 16-31.

De Diego, Estrella. (1992). El andrógino sexuado. Madrid: Balsa de la Medusa.

Delgado, Manuel. (1999). El animal público. Hacia una antropología de los espacios urbanos. Barcelona: Anagrama.

Didi-Huberman, Georges. (2014). Pueblos expuestos, pueblos figurantes. Buenos Aires: Manantial.

Fontcuberta, Joan. (2002). El beso de Judas. Fotografía y verdad. Barcelona: Gustavo Gili.

Grigoriadou, Eirini. (2012). "El espacio urbano en las prácticas fotográficas de la Escuela de Düsseldorf”. De Arte, núm. 11, 167-184.

Guasch, Anna Maria. (2011). Arte y archivo, 1920-2010: Genealogías, tipologías y discontinuidades. Madrid: Akal.

Hebdige, Dick. (2004). Subcultura. El significado del estilo. Barcelona: Paidós.

Howgate, Sarah. (2017). “Curious spirits”. En Sarah Howgate, Sawn Ades y Gillian Wearing, Gillian Wearing and Claude Cahun: Behind the Mask, Another Mask. Princeton: Princeton University Press, 8-20.

Lapeña Gallego, Gloria. (2014). "El caminar por la ciudad como práctica artística: desplazamiento físico y rememoración”. Ángulo Recto. Revista de estudios sobre la ciudad como espacio plural, vol. 6, núm. 1, 21-34.

LeVitte Harten, Doreet. (2002). "Melodrama”. En Melodrama [cat. exposición]. VitoriaGasteiz: Artium, 215-224. 
Lubow, Arthur. (2003). “Arbus Reconsidered”. The New York Times Magazine, 14/09/2003. Recuperado de: http://www.nytimes.com/2003/09/14/magazine/arbus-reconsidered. html?pagewanted=all (Fecha de acceso: 15/06/2017).

Lugon, Olivier. (2010). El estilo documental. De August Sander a Walker Evans 1920-1945. Salamanca: Ediciones Universidad de Salamanca.

Mayayo, Patricia. (2011). Cuerpos sexuados, cuerpos de (re)producción. Barcelona: UOC.

Moore, MacDonald y Moore, Deborah Dash. (2006). "Observant Jews and the Photographic Arena of Looks". En Vincent Brook (Ed.), 'You Should See Yourself': Jewish Identity in Postmodern American Culture. Piscataway (NJ): Rutgers University Press, 176-204.

Morris, Meaghan. (2006). Identity Anecdotes: Translation and Media Culture. London: Sage.

Muñoz-Muñoz, Ana M. y González-Moreno, María Barbaño. (2014). "La mujer como objeto (modelo) y sujeto (fotógrafa) en la fotografía”. Arte, Individuo y Sociedad, vol. 26, núm. 1, 39-54.

Nochlin, Linda. (1989). "Why Have There Been No Great Women Artists?" En Linda Nochlin, Women, Art, and Power: And Other Essays. Boulder: Westview Press, 145-179.

Núñez, Isabel y Oliva, Lydia. (2011). Sinrazones del olvido. Escritoras y fotógrafas de los siglos XIX y XX. Barcelona: Icaria.

Pollock, Griselda. (2008). Vision and Difference. Feminism, femininity and the histories of art. London: Routledge.

Prieto Aguaza, Alberto. (2014). Ventanas, espejos y sombras: imagen analógica y textualidad en Wright Morris, Duane Michals y Sophie Calle. Zaragoza: Prensas de la Universidad de Zaragoza.

Pultz, John. (2003). La fotografía y el cuerpo. Madrid: Akal.

Redondo Velasco, Ramón Laurentino. (2011). "El Bowery fotografiado por Martha Rosler". Espacio, Tiempo y Forma. Serie VII, Historia del Arte, núm. 24, 385-393.

Sanmartín, Ricardo. (2005). Meninas, espejos e hilanderas. Ensayos en Antropología del Arte. Madrid: Trotta.

Solomon-Godeau, Abigail. (2001). "La fotografía tras la fotografía artística". En Brian Wallis (Ed.), Arte después de la modernidad. Nuevos planteamientos en torno a la representación. Madrid: Akal, 75-86.

Sontag, Susan. (1996). La enfermedad y sus metáforas y El sida y sus metáforas. Madrid: Taurus.

-. (2006). Sobre la fotografía. México D.F.: Alfaguara.

Trasforini, Maria Antonietta. (2009). Bajo el signo de las artistas: Mujeres, profesiones de arte y modernidad. Valencia: Universitat de València.

Vadillo, Marisa. (2010). Otra mirada. Las fotógrafas de la Bauhaus. Servicio de publicaciones de la Universidad de Sevilla.

Weissman, Terri. (2011). The Realisms of Berenice Abbott: Documentary Photography and Political Action. Berkeley: University of California Press. 